\title{
Ex-Expedicionário Assume a Titularidade de Direito Econômico.
}

\section{A Redação}

O professor Dr. Geraldo de Camargo Vidigal, ex-expedicionário do primeiro batalhão do $6 .^{\circ}$ regimento da Infantaria, que militou na Itália em 1944 e 1945, no 1. ${ }^{\circ}$ escalão da FEB, após intensa vida jornalística, poética e advocatícia, assume a titularidade de Direito Econômico na Faculdade de Direito da Universidade de São Paulo. de 1921.

O novo titular nasceu em São Paulo, aos 18 de novembro

É filho do Dr. Alcides da Costa Vidigal e de D. Tercília de Camargo Vidigal, já falecidos.

Casou-se em 1947, com D. Elsie Facó Vidigal.

Fez o curso ginasial único no Colégio São Luís de São Paulo, de 1933 a 1937, e a seguir o Curso Pré-Jurídico, anexo à Faculdade de Direito da USP. Ingressando na mesma Faculdade em 1940, graduou-se em Ciências Jurídicas e Sociais em 1945 .

Desde cedo, militou no jornalismo e aos 16 anos participava, com Paulo Nogueira Neto e José Bonifácio Coutinho Nogueira, da direção do jornal estudantil, América.

Participou, ativamente, da vida política e literária da Academia, durante seu tempo de estudante, tendo, inclusive, fundado em 1943 a Frente Acadêmica pela Democracia, do qual foi o primeiro presidente e cujo manifesto redigiu, com Luiz Gonzaga Arrobas Martins e José Carlos Moraes Abreu. Como conseqüência, naquele período ditatorial, foi convocado com outros três acadêmicos, também participantes da Frente Acadêmica, para a Força Expedicionária Brasileira que lutava na Itália contra o hitlerismo, integrando então $0 \quad 6 .^{\circ}$ Regimento de Infantaria. 
Pela atuação militar recebeu elogios oficiais e a inscrição de seu nome, com os de outros alunos e ex-alunos, em placa de bronze afixada no saguão das Arcadas.

Também na Itália exerceu atividade jornalística, fundando, com outros companheiros, um periódico do $10^{\circ}$ Batalhão, que se denominou $E$ a Cobra Fumou, frase que se tornou símbolo dos expedicionários, e do qual foi o primeiro redator chefe. $O$ Vanguardeiro foi outro Boletim noticioso do $6 .^{\circ}$ Regimento, fundado pelo então soldado Geraldo de Camargo Vidigal, no qual exerceu simultaneamente todas as funções jornalísticas, desde a de repórter as de datilógrafo e redator único.

Em 1944, enquanto esteve na Itália, foi publicado no Brasil, seu primeiro livro de poesia, Predestinação, que teve prefácio de MÁRIO DE ANDRADE.

Em 1946, iniciou atividade advocatícia, mas, não abandona o jornalismo e a poesia e em 1948 funda a Revista Brasileira de Poesia, de cujo Conselho Diretor participou; em 1952 publica outro livro de poesia, Cidade. Dedica-se, então, mais ativamente ao Direito, e publica em 1964, a dissertação para Concurso, realizado em 1965, Disciplina dos órgãos de Direção Monetária, conquistando a livre-docência de Economia Política, nesta Faculdade.

Exerce, então, ao mesmo tempo, a livre-docência de Economia Política e a advocacia, e publica, ainda, em 1971, outros poemas coligidos sob o título Cantares de Amor e Solidão.

Já livre-docente de Economia Política, e assistente do Professor Pinto Antunes, presta concurso de provas e títulos, em 1972, conquistando a livre-docência de Direito Financeiro com a tese Fundamentos do Direito Financeiro. Essa tese recebeu ampla edição em 1973. Em 1973, por concurso de títulos, torna-se professor adjunto à mesma cadeira.

Além de toda a atividade docente, advocatícia, jornalística e poética, o professor Geraldo de Camargo Vidigal foi também presidente do Instituto dos Advogados de São Paulo no biênio 1975-77, após exercer sua vice-presidência e de haver colaborado como conselheiro em vários triênios. $\mathrm{Na}$ Ordem dos Advogados do Brasil, secção de São Paulo, foi conselheiro em dois mandatos. No Instituto dos Advogados fundou e redige a Análise Jurisprudencial.

Atualmente é chefe da Assessoria Jurídico-Econômica da Federação Brasileira das Associações dos Bancos e da Asso- 


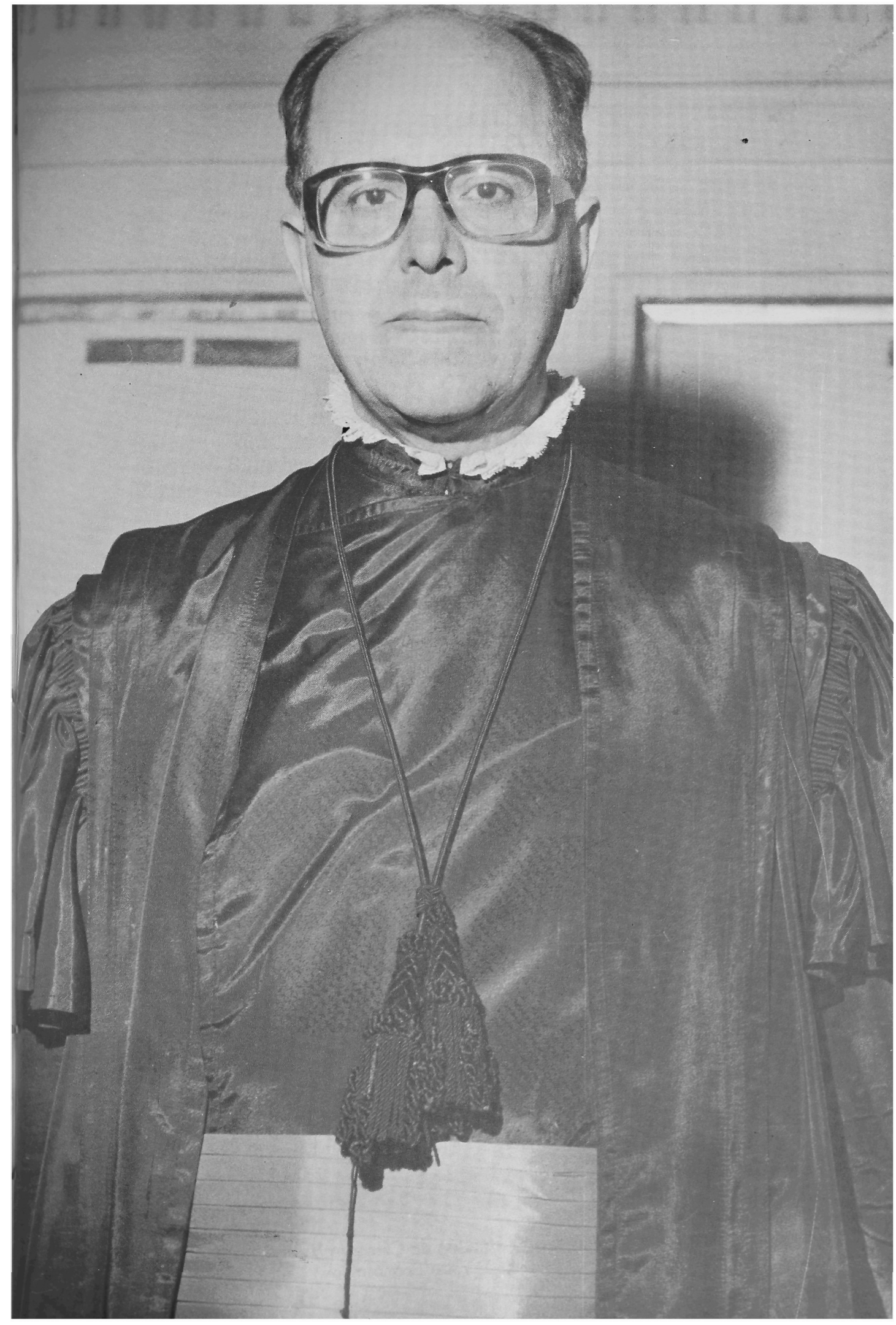


Professor Doutor Geraldo de Camargo Vidigal, Titular de Direito Econômico 
ciação dos Bancos do Estado de São Paulo, onde fundou a revista Balancete Mensal; prepara um livro de poesias; conclui um ensaio filosófico sobre a natureza do Tempo e dirige uma coleção de comentários sobre a disciplina das Sociedades Anônimas, em parte já publicados.

Em 1976, com a tese Objeto do Direito Econômico, submete-se a concurso para a titularidade de Direito Econômico, disciplina que pela primeira vez se colocou em concurso, no Brasil.

Constituiam a banca examinadora os professores Oscar Barreto Filho, Antônio Roberto Sampaio Dória de São Paulo; Aliomar Baleeiro, Rubens Requião, do Paraná e Washington Peluso Albino de Souza, de Belo Horizonte.

Aprovado, por unanimidade, com a média 8,8 , é nomeado a 12 de agosto de 1976 e toma posse do cargo no mesmo dia.

\section{Bibliografia.}

É a seguinte a bibliografia do professor Dr. Geraldo de Camargo Vidigal:

1. Predestinação, poemas, com prefácio de MÁRIo DE ANDRADE, 1945.

2. Cidade, poesias, 1952.

3. Disciplina dos órgãos de Direção Monetária, dissertação para o concurso de livre Docência de Economia Política, 1965.

4. Cantares de Amor e Solidão, poemas, 1971.

5. Fundamentos do Direito Financeiro, dissertação para o concurso de livre docência de Direito Financeiro, 1972 e 1973.

6. Distribuição de Receitas Tributárias, Comentários ao Código Tributário Nacional, v. 2, 1976.

7. Objeto do Direito Econômico, dissertação para concurso à titularidade de Direito Econômico, apresentada à FDUSP em 1976 e editada em 1977 com o título Teoria Geral do Direito Econômico.

\section{A Recepção do Novo Titular.}

A 12 de novembro de 1976, a Congregação de Professores reúne-se no salão nobre, às 20 horas, para receber solenemente o novo titular. 
Preside à mesa o diretor da Faculdade, Professor Dr. RUY Barbosa Nogueira, que designa os professores Miguel Reale, GOFFREDo TELLES JÚNIOR e ANTÔNIo CHAVES para introduzir no doutoral o professor Dr. GERALdo DE CAMARGo VIDIGAL.

É dada a palavra, então, ao professor Dr. CELso NEVES, que, em nome da Congregação, saúda o titular de Direito Econômico.

$\mathrm{O}$ orador tece inteiras páginas de arte ao transmitir a imagem do colega e amigo; e "diluindo interferências para ver delineados os círculos, as linhas, os símbolos", desvenda a personalidade do homenageado, situando-o, primeiro na família, depois na Academia revolucionária de 1937 a 1945, no estudo, na poesia, investindo afinal no Direito até chegar à Congregação das Arcadas no "exato momento da definição".

A seguir o homenageado, em peça igualmente poética, como não podia deixar de ser, agradece a saudação dos colegas; rememora as várias fases de sua vida, a influência da família em seu amor ao Direito e à Faculdade; a influência dos poetas Acadêmicos e de colegas ilustres em seu amor à posia; e as tradições Acadêmicas em sua vida militar, que lhe valeram a desejada placa de bronze no saguão de pedra das Arcadas. Confessa que seu ideal ao tornar-se aluno da Faculdade de Direito da USP era o de conquistar a glória de uma placa, ao lado daquelas que em nossas Arcadas imortalizam CASTRo Alves, Álvares DE AZEvedo, FAGUndes VAREla e que nem só a poesia competia com o Direito, mas também a Política.

Finalmente, relata os caminhos que o levaram a descobrir "nos ideais do desenvolvimento e do Bem-Estar Social, característicos de nossa época - novas formas do eterno ideal de Justiça", e como a aspiração do estudante a "soluções sociais de repartição mais justa e de organização produtiva mais eficiente", e mais tarde o trato e experiência na advocacia de instituições financeiras conduziram-no aos trabalhos, que lhe valeram o magistério universitário.

\section{A Saudação de Celso Neves.}

Quando recebi a notícia de que este exato momento iria acontecer, exultei na alegria da lembrança que alguém teve e que me faz estar aqui, e fiquei a imaginar o que lhe haveria de dizer, de meu, de profundamente meu, que fosse também de todos nós, profundamente de todos nós, porque em nome de todos lhe deveria falar, quando este exato momento che- 
gasse. E se a alegria veio espontânea, transbordante - porque é sempre espontânea, transbordante, a alegria de quem uma lembrança amiga faz transformar um dia qualquer, igual a qualquer outro, num dia determinado, diferente, excepcional - a imaginação fez-se-me em círculos de confusão, em linhas de superposição, em símbolos de indefinição. Afinal, que lhe diria eu, neste exato momento, que fosse algo de você, para você, e viesse de mim, de todos nós, para acentuar este exato momento de consagração, de uma consagração que é sua, essencialmente sua, e pudesse marcar o signo dessa predestinação?

Para que o pudesse fazer, era necessário, primeiro, eliminar as interferências, para deixar claros os círculos, as linhas, os símbolos. . Era preciso ordená-los, a todos - círculos, linhas, símbolos - para a síntese que me preocupava, porque nela haveria de estar o sentido exato de uma mensagem que deveria ser fiel ao pensamento de todos nós, autêntica, capaz de definir o sentido exato deste exato momento. Depois, passaria às abstrações do acidental, do transitório, para fixar-me no essencial, no perene, no intransmudável, para chegar a você, meu caro Geraldo, como você é, em suas dimensões verdadeiras.

Não me pareceu fácil - confesso - a superação, porque a sua imagem transmaterial, íntima, exuberante, na eloqüência de seus predicados, dava pouca margem ao acidental e era imprescindível reduzir o essencial ao momento exato deste exato momento. Percebi, ademais - verdadeira - a inconseqüência de quem

"no haya sentido la tentación de destruir el lenguage e de crear otro, aquél que no haya experimentado la fascinación de la no-significación y la no menos aterradora de la significación indecible",

na advertência singular desse admirável Octavio PAZ que, em poema de antes, me revelava o caminho, com estes grandes pequenos versos de Noche en Claro:

"Todo es puerta

Basta la leve presión de um pensamiento

Se abre de par en par la vida".

Basta a leve pressão de um pensamento, para que se abra, de par em par, a vida, porque tudo é porta. 
Vi então, no passado remoto, este mesmo sítio, em que, embuçados na estamenha pobre de uma Ordem venerável, andavam frades, em preces e solilóquios, a sonhar sonhos de fé, a brincar de esperança, a viver a ternura de uma caridade humilde e recolhida, enquanto lá fora o vilarejo ensaiava suas primeiras praças, e ruas, e vielas... Sim, por aqui andaram frades - irmanados pela devoção de uma obra de luz, nascida para lá dos mares, naquela estranha encosta que domina as planícies da Umbria.

Vi também - em passado mais próximo, de quase ontem - na parede do átrio desta Casa, exatamente na face que dá para o Largo de São Francisco - à destra da nobre figura de JosÉ BoNIFÁcIo, o Moço que hoje ali se aloja — uma placa de bronze, a assinalar que por aqui andaram moços que também daqui partiram - já mais de trinta anos são passados - para a afirmação de nossos ideais de liberdade, nos contrafortes dos Apeninos. Os círculos, as linhas, os símbolos, começam a definir-se.

Entre esses moços, um havia que já cedera ao sortilégio da velha morada paulistana da Ordem Seráfica de São Francisco de Assis, desde o momento em que dela se aproximara, em 1938, ao ingressar no Curso Anexo - depois do noviciado a que se submetera, de 1933 a 1937 - sob a disciplina segura dos Jesuítas. Se aí formara a sua estrutura de menino, aqui, no limiar da juventude, logo sentiu a fascinação dos ideais franciscanos. Antes mesmo de vencer os vestibulares, já era um estudante de Direito da mesma Academia em que se haviam formado, em 1916, ALCIDES DA CosTA VIDIGAL, seu pai advogado de escol, homem de altíssima dignidade que legou a seus filhos o exemplo de uma grande vida - em 1879, AFrodisio VIDIGAL, seu avô paterno, um dos fundadores da Fraternidade Literária e, em 1866, Álvaro DE CARVALHo - seu tio avô e um dos idealizadores da reunião de 18 de novembro de 1889 , em prol da República e do Governo Provisório.

Letras e ideais democráticos são marcos atávicos no estudante que, em 1944, se fez soldado e escreveu Predestinação, pondo na oferenda sem atavios uma explosão afetiva: "a meu Pai". Depois, Cidade, em que leio, comovido, a denúncia dos que "buscam o poema no mundo das palavras, em estado de dicionário", "Porque só da visão dramática do Eu ou da visão dramática do Mundo nascem Arte e Poesia: e o pequeno mundo 
das palavras apenas fornece aos poetas dotados de autenticidade interior, os indispensáveis fios condutores de corrente lírica".

Todo o lirismo do poeta que denunciava "a heresia formalista" tinha, naquele exato momento, uma direção emocional: Elsie, a quem o livro é dedicado e que tomara por esposa, em fevereiro de 1947, naquela amorável igrejinha do outeiro da Glória. Nele se reúnem versos de 1945 a 1950, a maioria de 1946, ano em que colara grau de bacharel em Ciências Jurídicas e Sociais e passara, com as mesmas convicções e o mesmo idealismo, a enfrentar as responsabilidades que a vida a ele oferecia, assumindo-as a seu modo, com aquele desembaraço de quem sabe o rumo certo, não teme encruzilhadas, tem pressa e convicção de vencer, sem o orgulho estulto dos que aspiram às vitórias de oportunidade, vazias de conteúdo, sem réstea de qualquer ideal.

Basta a leve pressão de um pensamento, para que se abra, de par em par, a vida...

Quando essas coisas se ajustavam em meu espírito, vi ainda a visão mesma dos fastos que levaram esta Faculdade a se inclinar aos moços símbolos, naquele bronze votivo, porque souberam reafirmar, no momento exato de um exato momento, a grandeza das Arcadas, honrando as suas tradições de liberdade.

Alí estavam, para exemplo dos pósteros, nomes de heróis. Dentre eles o do praça 4.396 , do $1 .^{\circ}$ Batalhão, do $6 .^{\circ}$ Regimento de Infantaria, da Força Expedicionária Brasileira, calando a sua bravura, o seu idealismo, a sua fé, a sua ternura poética. Foi ele o redator de $E$ a Cobra Fumou..., de $O$ Vanguardeiro, o mesmo soldado que mereceu, por sua bravura, a Medalha de Campanha, com que foi agraciado. Nem mesmo ali, nos entreveros da luta, deixava de vibrar a sua vocação literária que, aos 16 anos, o levara a participar da direção do jornal estudantil América e a fundar, depois, com outros nomes de suma evidência das nossas letras, a Revista Brasileira de Poesia. Nem mesmo ali, nos entreveros da luta, esquecia a sua Faculdade.

Estou quase certo de que, neste exato momento - meu caro Geraldo - você estará vendo, entre os que aqui estão, o velho Elvino Fiume, com o mesmo semblante dos dias de Via Faenza, a aplaudi-lo, em mais este momento de vitória... 
Em sua mensagem de 11 de agosto de 1944, aos colegas desta Faculdade, vinda da península que os romanos imortalizaram, há teor de confissão:

"Nesta data, que é a nossa, sinto como nunca a distância que me separa das Arcadas. Meu conforto é a consciência de que combato, mais intensamente do que nunca, pela mística a que dediquei a minha mocidade."

Seu voto de 10 de novembro desse ano, para as eleições do nosso centro, veio da Itália - testemunho de sua vocação democrática e de seu entranhado amor pela Academia.

Círculos, linhas e símbolos se ordenam em meu espírito, e entrevejo, depois, o sentido emocional da sua existência, voltado para a família que tão bem constituíra e que lhe dera a alegria incomparável de seus cinco filhos: Elisabeth, Alcides, Geraldo, Edgard e Cecília Maria. Vejo, ainda, o poeta, feito jurista, voltar seus olhos para o Capítulo mais alto desta Casa - a sua Congregação de Professores. Já então, tocado pelo seu fascínio, era a escalada para a Cátedra que passara a preocupá-lo. Sua alma pôs-se em vendaval. Já de si inquieto e impetuoso, inquietação e ímpeto fizeram-se turbilhão, em sua vida de trabalho intenso.

Disciplina dos órgãos de Direito Monetário, escrita em 1964, é a dissertação com que, em 1965, conquistou a Livre Docência de Economia Política. Em 1972, sobrevém Fundamentos do Direito Financeiro, com que alcança a Livre Docência nessa matéria.

Catedrático substituto de Ciência das Finanças em 1968, regeu essa disciplina até 1972 , período no qual passou ela a denominar-se Direito Financeiro. Em 1972-1973 regeu substituindo a PINTo ANTUNES - a disciplina de Direito Econômico, no primeiro ano do curso de graduação. Professor Adjunto desde 28 de novembro de 1973, em 1974-1975 lecionou Direito Econômico Aplicado, no $5^{\circ}$ ano de graduação. Ainda em 1975, encarrega-se da regência da disciplina de Direito Econômico Comparado, no curso de pós-graduação, aberta com o falecimento do nosso saudoso Pinto ANTUNES, e nesse mesmo ano publica Distribuição e Receitas Tributárias.

Além disso e das intrincadas atividades de advogado, de consultor e dirigente de órgãos de classe, ministrou, em 1971, 
curso de extensão cultural sobre direito do desenvolvimento, tendo participado, também, de bancas de concurso à livre docência de Economia Política, na Faculdade Nacional do Paraná, e de doutoramento, nesta Faculdade.

Em 1975 é eleito Presidente do Instituto dos Advogados de São Paulo - a que pertence desde 22 de Março de 1949 para o biênio de 1975-1976. Não será necessário descer a minúcias quanto às suas demais atividades, no campo do estudo e da divulgação do direito, especialmente nas disciplinas de sua predileção.

Finalmente, com a tese Objeto do Direito Econômico, ascendeu à titularidade dessa cadeira que hoje, solenemente, assume, mediante concurso brilhante, realizado em junho deste ano, razão mesma deste momento em que, por direito de conquista, toma posto definitivo na Congregação de Mestres desta Faculdade.

\section{Meu caro Geraldo}

Durante esse longo período de sua vida, viveu você nos anseios perenes de quem busca legar a seus descendentes, se possível acrescidas, as mesmas tradições de dignidade, cultura e civismo herdadas de seus nobres ascendentes. As suas próprias amarguras são vestes de névoa em sua sensibilidade que a crença mais engrandece; as suas incertezas quem por elas não passa? - têm sido o desafio de que nascem os rumos da sua certeza!

Assim tem sido você, desde aqueles dias que a saudade aproxima, trazendo-os ao momento exato deste exato momento. Assim é você, na sua exuberante alegria de viver, na sua permanente inquietude, no seu constante lirismo, a transformar, muitas vezes, a escalada íngreme das vicissitudes, em transbordamentos de beleza que só a fé pode explicar.

É assim que nós, seus companheiros de Congregação desta Faculdade, o vemos, neste momento de triunfo, em que se realiza o mais alto sonho com que pode sonhar um sonhador como você, vencido pelo sortilégio deste chão de nossas esperanças, solo de nossos ideais, terra nossa que é síntese dos círculos, das linhas, dos símbolos que fazem a essência de cada um de nós.

Quando se atinge, assim, posto definitivo na Congregação desta Faculdade, é que um exato momento chegou, em seu exato momento; é que os círculos, as linhas, os símbolos, 
se definiram, para acentuar o sentido de uma vida que se faz grande, pela grandeza da flama que a incendeia, maior ainda pela soma das vitórias somadas, insuperável, pela realização plena dos sonhos de alguém que mal esconde, na gravidade severa de sua postura, nas horas de responsabilidade, a alegria que estoura nos entretempos de convívio amável, em gargalhadas que poucos, hoje, sabem dar e que definem uma exuberância de alma pela qual se explica a ternura lírica do poeta que está em todo o seu ser, para dar-lhe a beleza de quem se sente

de quem,

"Livre do espaço e do tempo",

“. . em derredor, feliz, semeia

os grãos de luz"

porque alcançou o esplendor e é o que sempre quis ser, honrando, com sua postura, a seus maiores, para dar a todos nós a alegria exata deste exato momento, em que os círculos, as linhas, os símbolos convergem para uma consagração que realiza o signo de sua predestinação. E daqui pr'a frente, meu caro Geraldo, eu o vejo como o Guardador de Rebanhos que

"Conhece o vento e o sol

$\mathrm{E}$ anda pelas mãos das Estações

a seguir e a olhar"...

sempre o mesmo, na essência afirmativa de quem se encanta com crepúsculos, se enternece com o luar, se entusiasma com o amanhecer e abre os braços, para abraçar a vida, a cada dia que nasce!

\section{Discurso de Agradecimento do Novo Titular.}

Mais de trinta anos após graduar-me bacharel, mais de dez anos após prestar aqui meu primeiro concurso à livredocência, quase quarenta anos após os dias em que, na qualidade de aluno de seu curso prejurídico, pisei o Largo São Francisco - dá-me a nossa querida Academia a honra de receber-me entre os seus professores titulares. E esmerou-se na honraria concedida, fazendo publicá-la no Diário Oficial do dia 12 de agosto, o primeiro dia deste ano do Sesquicentenário da fundação dos cursos jurídicos no Brasil.

Chego quando já desce o meu crepúsculo. Alguns passos além das portas deste Salão Nobre, na discreta sala de reu- 
niões da Congregação, dispõem-se, em quatro linhas, os professores titulares desta Casa, segundo a ordem cronológica dos momentos em que se completou a carreira universitária de cada um. Devesse eu sentar-me entre meus companheiros de geração acadêmica e iria ocupar uma das poltronas da fileira inicial. Cabe-me, entretanto, o último lugar da última fileira: nas cadeiras finais da primeira linha e nas três outras, figuram, é verdade, alguns colegas de turma acadêmica, como Anacleto de Oliveira Faria e Ruy Barbosa Nogueira - mas dominantemente se distribuem calouros meus, como Alexandre Augusto Correa, Vicente Marotta Rangel, Oscar Barreto Filho, Manoel Pedro Pimentel, ou mestres muito mais jovens, como Manoel Gonçalves Ferreira Filho, Dalmo de Abreu Dallari, Sampaio Dória, José Afonso Silva, e mesmo juristas eminentes que, no início de sua carreira, orgulhei-me de orientar nas lides forenses - como é o caso do professor Fábio Comparato.

Principiei minha carreira universitária, realmente, na idade em que a grande maioria dos meus colegas já a completou, o que me veda incluir, entre minhas aspirações da velhice, as glórias do decanato acadêmico.

Não me pesa ter chegado tarde ao encontro. Envaideço-me, em verdade, por ter cumprido, na casa dos 40 e dos 50 anos, as duras provas do noviciado universitário. Não há, entretanto, como aqui omitir explicações de porque chegou tão tarde à Academia de São Francisco quem, desde menino, nunca dela se separara.

Aprendi a amar a Faculdade, conheci suas tradições ouvi de suas lendas pela voz de meu avô, Afrodísio Vidigal, o grande advogado de quem, desde meus cinco anos, em 1927, e até sua morte, em 1938, fui talvez o companheiro mais constante. Aprendi a amar o Direito, voltei-me para os ideais de Justiça pelo exemplo e pelo ensinamento de meu pai, Alcides da Costa Vidigal, advogado em quem se reuniam todas as qualidades que engrandecem o Foro, meu mestre, meu exemplo quase meu oráculo, vocação admirável de educador, a quem só o exercício estóico de outros deveres impediu, por duas vezes, fosse concretizada a intenção que teve de candidatar-se ao magistério nesta Casa.

Quando me tornei aluno de São Francisco, amor, ideal e atavismo se davam as mãos. Revivia, em mim, o espírito do Marquês de Monte Alegre, José da Costa Carvalho, irmão de meu trisavô, e estadista que ocupou, na vida brasileira, os três cargos de maior relevância: Regente do Império, Pre- 
sidente da Província de São Paulo, Diretor desta Faculdade do Largo de São Francisco.

Tardei, entretanto, em dedicar-me ao Direito como ciência. 0 que me deteve, acredito, foram principalmente as seduções da arte poética, que dominaram, na juventude, o meu espírito. O clamor de Castro Alves, ao cantar:

$\mathrm{Eu}$ sinto em mim o borbulhar do gênio

a doçura de Azevedo, no retratar-se

Foi poeta, sonhou e amou na vida

a angústia de Varela, sintetizada na queixa

Tornei-me o eco das tristezas todas

Que entre os homens achei,

a dicção melancólica de Vicente de Carvalho, advertindo

Só a leve esperança, em toda a vida,

Disfarça a pena de viver!

a "trouvaille" de Oliveira Ribeiro Neto

Teu nome, velha Faculdade,

E a melhor das rimas para liberdade

o coro, enfim, dos poetas da Academia de tal maneira me seduzira, que meu alvo, ao tornar-me seu aluno, era o de conquistar a glória de uma placa ao lado daquelas que, em nossas Arcadas, imortalizam Castro Alves, Álvares de Azevedo, Fagundes Varela, Oliveira Ribeiro, uma placa ao lado daquela que deveria celebrar a imortalidade de Vicente de Carvalho. Transpostos os umbrais da Academia, a convivência com Péricles Eugênio da Silva Ramos, com Lygia Fagundes Telles, com Mário da Silva Brito, com Israel Dias Novais, com Ruy Galvão Coelho, com Paulo de Tarso Santos, com Severo Fagundes Gomes, com David Silveira da Motta Junior e tantos outros - iria alimentar e manter vivas as ambições de realização poética.

Mas nem só a poesia pretendeu competir com o Direito. Meu vestibular para o Pré-jurídico foi prestado apenas alguns dias após o 10 de novembro de 1937; meu grau de bacharel foi obtido semanas após o golpe que depôs, em 1945, o governo de Getúlio Vargas, a quem eu podia debitar não só a agressão ideológica implícita nos movimentos de seu jogo político, não só a angústia provinciana da ocupação militar de São Paulo e das humilhantes interventorias militares, como os sentimentos vinculados à morte, no exílio, de meu tio Ioiô, o senador paulista Álvaro de Carvalho, grande nome que 
poderia personificar o período histórico da Política dos Governadores. Envolvi-me, por todos esses motivos, no grande abraço que uniu, no período 37-45, a inteligência paulista, e em especial a Faculdade de Direito de São Paulo, contra a opressão da ditadura Vargas.

Ao longo dos anos de São Francisco - vividos talvez mais em seu páteo que nas salas de aula, talvez mais no Centro Acadêmico XI de Agosto do que na biblioteca onde se reúnem os tesouros acumulados por tantas gerações acadêmicas ao longo dos anos de São Francisco dividi-me no serviço a esses três senhores tão exigentes, e de exigências tão diversas, como o são a Poesia, a Ciência Jurídica e a militância da resistência política. Essa militância, aliás, precedera meu ingresso na Faculdade, como um dos frutos da estreita amizade que desde muito cedo uniu fraternalmente, a mim e a meu irmão Marcello, os dois irmãos Paulo Nogueira Neto e José Bonifácio Nogueira.

Em 1943 - já então cursando eu o $4 .^{\circ}$ ano da Faculdade, Paulo o 3..$^{\circ}$ ano, Marcello o $2^{\circ}$, José Bonifácio calouro fundaríamos a Frente Acadêmica pela Democracia, de que fui o primeiro presidente e cujo manifesto, que procuramos fazer muito vibrante, redigi com Luiz Gonzaga Arrobas Martins e José Carlos Moraes Abreu.

O clima gerado pelo manifesto da Frente Acadêmica que precedeu de semanas o famoso manifesto dos mineiros resultou em que a polícia de Coriolano de Goes fechasse, menos de dois meses depois, o baile anual do Centro XI de Agosto, criando um movimento de comícios, passeatas, assembléias permanentes e, afinal, agressão policial que provocou a morte de um jovem e ferimentos em numerosos estudantes.

Relembro esses acontecimentos porque, por virtude deles, eu iria receber, de forma inesperada, não da Musa da Poesia lírica, mas da Deusa da guerra, a placa que sonhara merecer das Arcadas. Como um castigo às manifestações estudantis, após prisões que eu e outros estudantes sofremos, os jornais dos primeiros dias do ano de 1944 estampavam a notícia da convocação isolada de quatro estudantes para a Força Expedicionária Brasileira. Convocação original, pois os convocados eram nascidos em anos diferentes, um em Queluz, um em Limeira, dois em São Paulo. Um dos quatro era reservista de terceira categoria, outro de primeira, dois haviam feito Tiro de Guerra. O único ponto em comum era serem, aqueles quatro convocados, estudantes no Largo de São Francisco. 
Além do meu nome, abrangia a notícia o de Ruy Pereira de Queiróz, candidato da Frente Acadêmica à Presidência do Centro XI, o de José Vasques Bernardes, estudante de raro desassombro, e o de Naldo Caparica, que fora comigo designado para redigir o jornal do Partido Acadêmico Libertador, antes que eu o tivesse deixado para fundar a Frente Acadêmica pela Democracia.

Tenho consciência de que fui, no $6 .^{\circ}$ Regimento de Infantaria, em terras italianas, um soldado digno da Faculdade de Direito e do Centro XI de Agosto, como demonstraram os elogios militares que recebi, em combate e fora dele, as muitas missões cumpridas na Itália, freqüentemente como voluntário, assim como o jornal e o boletim que na Itália redigi: $E$ a Cobra Fumou, o lendário jornal do $10^{\circ}$ Batalhão do $6 .^{\circ}$ Regimento de Infantaria, de que fui o primeiro redator chefe, e que fundei ao lado do Major João Carlos Gross, do Tenente João Alfio Piazon, do Cabo Higino Correa, hoje meu aluno em nossa Faculdade, e $O$ Vanguardeiro, o boletim do $6 .^{\circ}$ Regimento, que fundei com o Major Abílio da Cunha Pontes, e de que fui redator único, repórter e datilógrafo. Assim, em meu regresso vi meu nome, ao lado dos de outros estudantes expedicionários, gravado em pedra no saguão das Arcadas e, ademais, inscrito em mensagem dos Professores da Casa que, até a Diretoria Pinto Antunes, permanecia, como um troféu da Faculdade, enquadrado e exposto em parede da sala do Diretor.

Foram em parte essas honrarias o que me distraiu de realizações jurídico-científicas; em parte maior, foi a repercussão do meu primeiro livro de poemas, bafejado pelas aliciadoras circunstâncias de que o poeta lutava como soldado do Brasil e merecera um prefácio de Mário de Andrade; em parte, a intensa atividade forense a que iria dedicar-me, apenas formado; em parte, o acaso que, na dicção de Raul de Leoni, vai a cada momento desviando

\section{"A linha leviana das estradas".}

Nunca me afastei, porém, das Arcadas. A lembrança de meu avô, a companhia de meu pai, de meu tio Gastão, de tantos primos que, desde Sylvio de Bueno Vidigal nelas se haviam formado para a vida, a elas me prendiam. A elas voltei sempre, dia a dia, a cada ato, a cada momento, a cada comemoração, por motivações de toda índole e até, vezes sem conta, apenas para visitá-las, para revê-las, para reavivar saudade que nunca se aplacava. Ninguém teria esquecido a sedução 
das eruditas lições, da alta pregação de um Waldemar Ferreira, de um Noé de Azevedo, de um Basileo Garcia, de um Miguel Reale, de um Canuto, de um Cesarino Junior, de um Luís Eulálio Vidigal - que então iniciava sua carreira universitária. Ninguém poderia, sem receber a marca de São Francisco, respirar o ar que a presença de um Ascarelli e de um Liebman enriqueceu. Ninguém poderia sem vinculação indelével, mergulhar, impulsionado pelas evocações de Almeida Nogueira, de Vampré, de Pelágio, de Pati e de tantos outros, na redescoberta de João Mendes, de João Monteiro, de Pedro Lessa, de Ruy, de Lafayette, de São Leopoldo.

O espírito da Faculdade me acompanhava sempre e a sedução do magistério em suas salas nunca me abandonou.

Pode parecer irônico que eu, bacharel em Direito e apenas autodidata em Economia, vivendo intensamente a vivência do processo judiciário e patrocinando sem interrupção centenas de causas em matéria civil e comercial, viesse afinal apresentar-me à Faculdade de Direito de São Paulo como candidato à livre-docência - que em 1965 conquistei — de Economia Política! Minhas indagações nessa área haviam nascido quando aluno da Faculdade, sob o impacto da aspiração a soluções sociais de repartição mais justa e de organização produtiva mais eficiente. Floresceram, mais tarde, ante informações colhidas e pela experiência de instrumentos observados na advocacia de instituições financeiras. Recebi, então, o estímulo de Sylvio Rodrigues, de Antônio Mercado Junior, de Luís Eulálio Vidigal, de Cardozo de Mello Neto, de meu tio Paulo Teixeira de Camargo, de Olavo Egydio Setubal, de Rubens Vidigal, de Gastão Eduardo Vidigal, estímulos sem os quais não teria realizado os trabalhos com que me apresentei perante a Faculdade, nem me teria animado à concretização de minha candidatura ao magistério universitário. Quis o destino que minha carreira universitária só se iniciasse após a morte de meu pai a quem tudo devo e que com ela teria vibrado!

Contemplando hoje a variedade dos caminhos que percorri no universo jurídico, na indagação econômica, na militância política, na intensa atividade do foro, na vivência poética, bendigo-os e agradeço a Deus pois de todos eles colhi dados para as sínteses que procurei construir do Direito Econômico. Analisando a evolução social desenvolvida ao longo dos dois últimos séculos e projetada nos mosaicos da realidade contemporânea, foi-me possível, porque trazia comigo aquelas vivências, descobrir, nos ideais do Desenvolvimento e do Bem-Estar 
Social - característicos de nossa época - novas formas do eterno ideal de Justiça. Fecundou-se, nessa evolução, o estéril Direito da sociedade liberal, que só vira a Justiça sob as aparências da paz, da ordem, da segurança, e que guardava, sob o formalismo do "suum quique tribuere", sob as fórmulas rituais do "stare decisis" sob as suposições que vieram a cristalizar-se na Escola da Exegese, sob brocardos do estilo do "caveat emptor", o apreço ao estático, ao árido, à superficialidade dos critérios da justiça comutativa, assim como os germes que responderam, nos mercados, pela recorrência dos tumultos, dos sobressaltos, dos desequilíbrios, das depressões, dos excessos de euforia. O exame aprofundado, a compreensão e a disciplina correta dos fatos jurídicos do mercado, a adoção de novas técnicas jurídicas para a disciplina econômica, o tratamento jurídico adequado da empresa, da iniciativa estatal, dos diversos agentes econômicos, hão de resultar do estilo peculiar que se instala quando as ideologias do desenvolvimento e do bem-estar impõem ao Direito uma nova ética, uma nova tessitura e uma nova substância.

Não devo omitir, na solenidade de hoje, minha homenagem à memória do Professor Pinto Antunes, que me acolheu de maneira cordial, como assistente à Catedra de Economia, que ocupava e que, por mutação, faria nascer a disciplina Direito Econômico, de que hoje me invisto titular, assim como às memórias dos saudosos Professores Teotônio Monteiro de Barros e José Barbosa de Almeida, aos quais substitui na docência de Finanças Públicas.

Quero agradecer de maneira muito particular as palavras carinhosas com que hoje me acolhe o Professor Celso Neves. Nos embates forenses em que nos defrontamos, na convivência que tivemos como conselheiros da Ordem dos Advogados ou como associados do Instituto dos Advogados de São Paulo, na leitura de suas obras, nas aulas e conferências suas a que assisti, aprendi ao longo de quase um quarto de século, a admirar progressivamente o advogado combativo e elegante, o cientista do Direito, agudo e profundo, o colega fraternal e sempre disponível, o estilista fulgurante e ágil, o amigo reto e leal.

Aos companheiros de Congregação, às autoridades e demais docentes, aos amigos, colegas, alunos e funcionários que me trouxeram o prestígio de sua presença, a todos agradeço. Sou devedor do funcionalismo da Faculdade, quer na Secretaria, nos Departamentos, na Biblioteca, pela assistência dedi- 
cada que sempre recebi. Dos alunos pelas dúvidas e objeções levantadas em aula, pelas pesquisas que trouxeram. Dos colegas, pelas lições deles recebidas.

Possam minhas palavras finais exprimir meu amor e minha gratidão àqueles a quem mais devo apoio, sacrifícios e renúncias que permitiram minha carreira universitária. A Elsie, mais do que a ninguém, por seu carinho, por sua compreensão, pelas noites de vigília, pelos dias de isolamento, pela sobrecarga de tarefas e responsabilidades domésticas que acolheu com doçura. Aos filhos e netos, que tenho privado tantas vezes de companhia e conselho, confiando em que o exemplo possa preencher o vazio. Aos companheiros de trabalho, que aceitaram substituições e suportaram deveres que me pertenceriam. Aos irmãos e ao grupo dos amigos íntimos, todos mantidos tão próximos, ao longo de toda a vida anterior e, afastados dos padrões anteriores de convívio, pelas exigências da carreira universitária.

Encerro minhas palavras, evocando com saudade meu pai, Alcides, e minha mãe, Cilita, representados nesta sala por Maria, minha segunda mãe, a quem agradeço o universo do que aos três ficou devendo, em devotamento, exemplo, orientação, amor, o Professor que hoje aprofunda suas raízes no chão de São Francisco. 